IJADR

International Journal of Alcohol and Drug Research

The Official Journal of the Kettil Bruun Society for Social and Epidemiological Research on Alcohol

doi: 10.7895/ijadr.v5i1.230

IJADR, 2016, 5(1), 13 - 14

ISSN: 1925-7066

\title{
Critical independence and personal integrity revisited
}

\author{
Paul H.H.M. Lemmens ${ }^{1}$ \\ ${ }^{1}$ University of Maastricht, Department of Health Promotion, Maastricht, Netherlands
}

In my contribution I will deal with the topic of conflicts of interests through four short stories about the potential harms in collaboration between research and industry. I will let you analyze the stories yourself and draw from them your own issues to be debated later.

1. I am a curious person, and when I got the invitation at the end of the 90s by former World Health Organization official Marcus Grant to join a discussion in Dublin on issues related to collaboration between the alcohol research world and the alcohol industry, I decided to join the meeting. It culminated in a consensus statement (Hannum, 1997). The trip was paid by the Dutch STIVA, a "front" organization of the Dutch alcohol industry.

I was curious to see whether the industry was willing to accept limitations in their freedom to act in this collaborative field. I suggested striving for what I called "rules of engagement"-rules by which transparency is secured and integrity of the researcher is guaranteed. I thought that to be of paramount importance, since the usual victim in the clash of the titans is the individual researcher.

My conclusion at the end of the Dublin meeting was that the industry was not willing to accept any restrictions in their dealing with the research field.

Although disappointed, I did sign the Dublin declaration, which relates to principles of ethical conduct; I feared that if I declined to sign the document, it would appear to reflect poorly on my character (Asare et al., 1997).

2. The second story is an example of reputation damage that followed the publication of a book by the Alcohol and Public Policy Project (Edwards, 1994). Two Scottish researchers were 'exposed' by The Independent as being in the pocket of the whiskey industry (Commentary The Independent, 1994; Doyle, 1994). A row over the Portman Group's engagement, involving one of the Edinburgh professors, inviting and paying researchers to critically review the book, even anonymously when so desired, led to the end of their appointment as professors at the University of Edinburgh. It had long been public knowledge that their
Alcohol Research Group received funds from the industry; yet the media commotion over the Portman action meant the end of the Alcohol Research Group. Loss of job appointments, reputations tarnished, and relations ruptured.

In my view, the accusations in the media were unjust, in the sense that what the Portman Group attempted was not really a threat, as it was done relatively in the open. The Portman group's critical review, it could have led to an open discussion. Besides, I usually review research anonymously; no harm in that either. What seems much more troubling to me is when industry uses "reputation" sneakily, tactics as applied by the pharmaceutical industry (Lemmens, 1997).

The industry is interested in researcher "independence" as a value, not in an ethical sense but in political-economical terms. They want to buy an unbiased opinionconclusions from a researcher-because the researcher can be trusted and they cannot. Once the researcher loses his good name and claim to independence, the industry simply moves on to the next researcher they want to use (Lemmens, 2000). And there's a seemingly limitless supply for them to choose from.

3. The article just referred to (Lemmens, 2000) was a commentary on an article on ICAP, an alcohol industrysponsored organization similar to the Dutch STIVA, which actively publishes scientific evidence on alcohol issues. ICAP was built in 1995 on the shoulders of Marcus Grant, which made him the risée, outcast, traitor to the alcohol research world at the time. ICAP's plan was to establish partnerships with researchers and policy makers and convince people that having a drink was a basic human right. Their approach has resulted in several incidents in which personal integrity was called into question.

One of these incidents involved Gerry Stimson, a muchacclaimed forerunner of the harm reduction movement in the area of illegal drug use. Under ICAP's editorship and sponsorship, he, along with others, published a book on harm reduction in the alcohol area (Stimson, Grant, Choquet, \& Garrison, 2007), in contrast to a total

Correspondence: Paul Lemmens, University of Maastricht, Department of Health Promotion, PO Box 616, 6200MD Maastricht/NL.

E-mail: p.lemmens@gvo.unimaas.nl

Keywords: industry funding; research ethics; self-regulation; conflicts-of-interest 
consumption approach. In response to the book, Addiction published an editorial viciously attacking his integrity (Caetano, 2008). Stimson was part of the editorial staff of Addiction at the time; hurt by this attack, he resigned from Addiction.

In harm reduction, drug use is accepted as a cultural, albeit illegal practice, accepted as a reality or fact of life. It is slightly odd that the harm reduction paradigm, so well accepted in the illicit drug field both on the political-ethical side and as a result of empirical research showing its benefits, would be considered unethical when applied to a legal substance, such as alcohol.

The aims of "less is better" and "zero is our goal," evident in the general public health approach in the alcohol arena at least in some cases, are not necessarily the same when dealing with illicit drug use.

While harm reduction attempts to de-politicize the drug user, the "derelict junkie," in favor of his own health and public health, the drinker and the act of drinking are increasingly politicized. While the drug research and policy world has moved onto a cultural level in its approach and view, the alcohol world seems more and more dominated by a medical-epidemiological focus on alcohol use, set solely in a public health frame (Fillmore \& Roizen, 2000).

4. My last story centers on a book I recently read by Kari Poikolainen (2014), acclaimed scientist and former research director of the Finnish Foundation for Studies on Alcohol. He attacks some "sacred truths" of the alcohol public health world, as well as what he terms the "alleged" detrimental effects of alcoholic beverages on one's health. He warns the reader that one should not unconditionally or uncritically believe what researchers in the alcohol field are suggesting. This book, by the way, is a fully independent publication.

It is quite remarkable that such an esteemed researcher feels the need to counteract the main message of the public health model after he ended his formal research career. Could it be that he was not at liberty to air such thoughts while working in the field? After the Kettil Bruun symposium, Kari Poikolainen told me he conceived of the actual book only after his retirement; so no grudge. He, though, recalled that twice governmental bodies declined to publish commissioned reviews by him because they included findings on beneficial effects of alcohol.

Recently the book received attention in the British press, including in The Independent (Jivanda, 2014). In the articles, he was misquoted as saying that one could drink up to 13 UK units of alcohol a day before getting into any danger. He was criticized, condemned even, for publishing this book. However appealing his message, the reception of this book shows that reputations can be easily damaged even when one is telling one's own truth.

\section{References}

(1994, December 6). Commentary: Academic integrity and alcohol abuse. The Independent, p. 15.

Asare, J., Le Bourhis, B., Crutcher, M., Diamond, I., Emblad, H., Grant, M., . . . Tsujisaka, T. (1997). Principles of cooperation among the beverage alcohol industry, governments, scientific researchers, and the public health community. European Addiction Research, 3, 205-206.

Caetano, R. (2008). About smoke and mirrors: The alcohol industry and the promotion of science. Addiction, 103, 175-178.

Doyle, L. (1994, December 4). Drinks companies pay dons to rubbish alcohol report. The Independent, Britain section page 00

Doyle, L. (1994, December 5). Pro-alcohol academics paid by drinks lobby. The Independent, p. 1

Doyle, L. (1994, December 5) Drinks industry picks up bill for researchers. The Independent, p3

Edwards, G. (Ed.). (1994). Alcohol policy and the public good (Vol. I). Oxford, England: Oxford University Press.

Fillmore, K. M., \& Roizen, R. (2000). The new manichaeism in alcohol science. Addiction, 95, 187188.

Hannum, H. (1997). The Dublin principles of cooperation among the beverage alcohol industry, governments, scientific researchers, and the public health community. Alcohol \& Alcoholism, 32, 641-648.

Jivanda, T. (2014, April 19). A bottle of wine a day is not bad for you and abstaining is worse than drinking, scientist claims; Former World Health Organisation expert reportedly believes alcohol is only harmful when you consume over 13 units in a day. The Independent online.

Lemmens, P. H. (1997). Buying research. Addiction, 92, 1077-1079.

Lemmens, P. H. (2000). Critical independence and personal integrity. Addiction, 95, 187-188.

Poikolainen, K. (2014). Perfect drinking and its enemies. Minneapolis, MN, United States: Mill City Press.

Stimson, G., Grant, M., Choquet, M., \& Garrison, P. (2007). Drinking in context: Patterns, interventions, and partnerships. New York, NY, United States: Routledge. 